Historic, Archive Document

Do not assume content reflects current scientific knowledge, policies, or practices. 



\section{Novelties and Rare Plants}

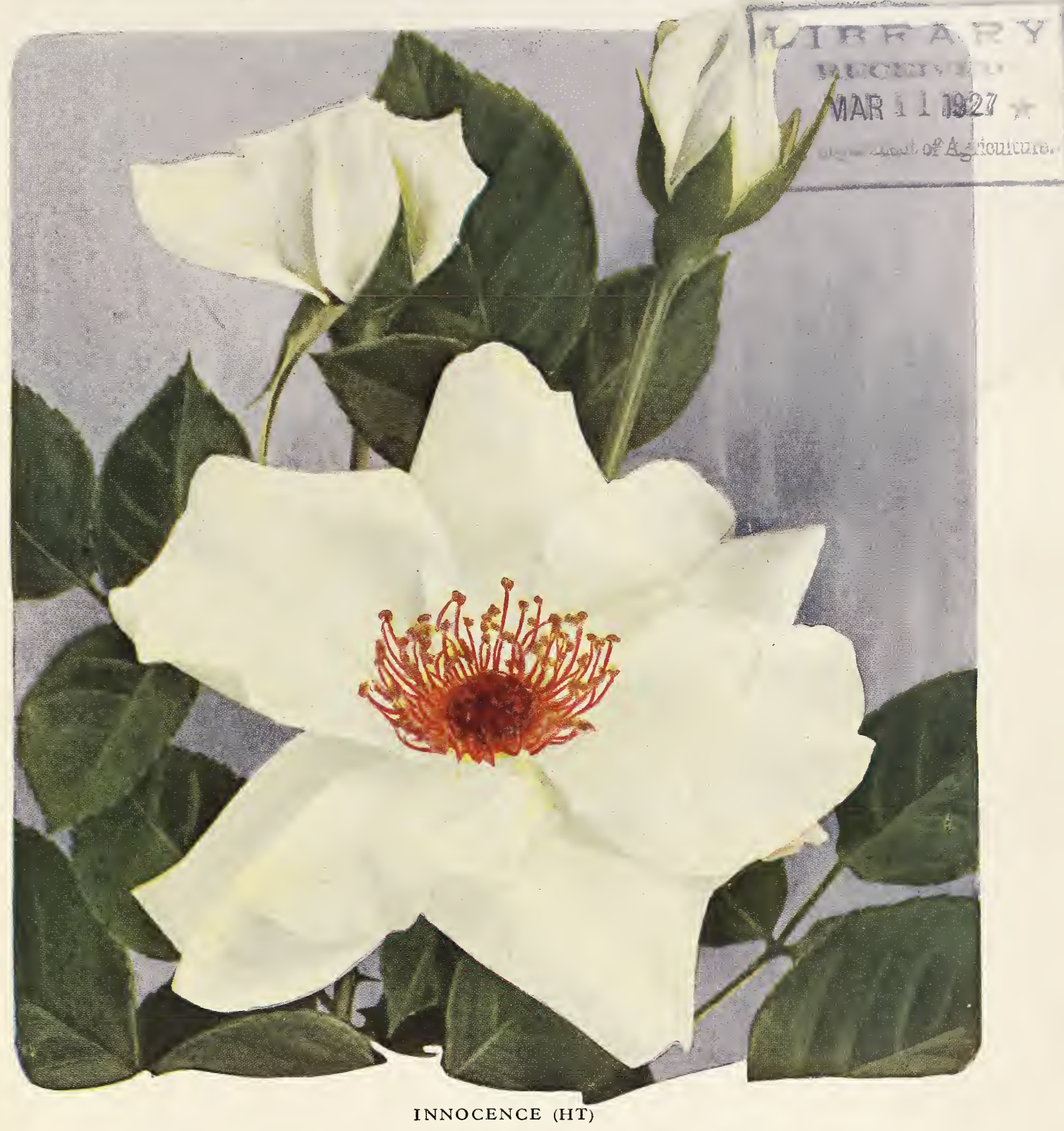

Bobbink\&Atkins

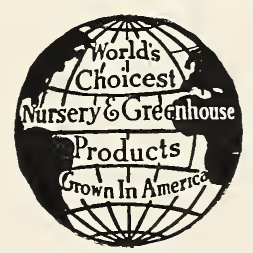

Rutherford NewJersey 


\section{A Herald of Spring}

7 HIS BOOKLET comes to call attention to many varieties of Roses, old-fashioned flowers, and nursery products often overlooked. It announces several novelties and rare plants which have not been listed in our Catalogues before. Here we list the novelties and rare roses and perennials.

"ROSES BY BOBBINK \& ATKINS" and its "SUPPLEMENT" describe hundreds of the more popular and lower priced varieties.

“HARDY HERBACEOUS PLANTS” describes hundreds of popular flowers which we cannot list in this booklet.

"EVERGREENS, TREES, SHRUBS, and VINES" contains descriptions of a choice collection in the above plants.

If you did not receive these publications last season, we shall be pleased to mail you any of them but it is important to state definitely what you intend to plant.

ORDER EARLY and state if we may replace sold-out varieties with others equally as good. This saves delay by correspondence. It greatly facilitates shipment if orders are received early, and will save disappointment.

IMPORTANT. Please advise when ordering, if you wish goods shipped by parcel post, express, or freight, giving best route for quick delivery. We will not warrant prompt delivery of goods shipped by freight. Please write Name, Post Office, County, and State, also Number of Street, plainly; also any other information necessary to expedite delivery.

We use our discretion as to best method of delivery unless otherwise instructed.
TERMS. Cash, or satisfactory reference must accompany all orders, unless the party ordering has an account.

HOW TO REACH OUR NURSERIES. Visitors invited. Our Nurseries, consisting of 500 acres, are located within 10 miles of New York City. The automobile roads leading to our Nurseries are exceptionally fine. Rutherford is the first and Carlton Hill the second station on the main line of the Erie Railroad. Take the Hudson Tunnel at 33d Street or at Cortlandt Street Terminal-trains connect with the Erie Railroad at Jersey City. The Carlton Hill Station is only five minutes' walk from our office and Nurseries.

\section{PARCEL POST INSTRUCTIONS}

If Dormant Roses are to be sent by Parcel Post, add to value of order, to cover postage and special packing as follows:

5 per cent additional to the following states: N. Y., N. J., Conn., R. I., Mass., Pa., Del., Md., N. H., Vt., Me., D. C., Va.

10 per cent additional to the following states: W. Va., Ohio, N. C., S. C., Tenn., Ind., Mich., Ky., Ala., Ga., Fla., Ill., La., Iowa, Mo., Miss., Neb., Wis. Okla.

15 per cent additional to the following states: Ark., Kansas, Minn., Tex., N. Dak., S. Dak.,

20 per cent additional to the following states: Wyo., Wash., Utah, Oregon, New Mex.,

Nev., Mont., Idaho, Ariz., Colo., Calif.

Potted Plants are sent only by express.

SPECIAL HANDLING. Parcel-post packages will be given better care and delivery hastened, for which the postal rate is 25c. extra on each package.

COLLECTIONS OF OUR SELECTION : 12 varieties Everblooming Roses, \$10; 25 varieties, $\$ 20$.

We will make no adjustments unless complaints are made within five days after receipt of stock. Complaints must be made direct to our office in writing. Your order is booked with this distinct understanding. All shipments at customer's risk.

While we exercise the greatest care to have all plants genuine and reliable, and are prepared to replace, on proper proof, all that prove untrue, we do not give any warranty, expressed or implied; and in case of any error on our part, it is mutually agreed that we shall not be held responsible for more than the original price of the plants.

\section{Bobbink \& Atkins, Rutherford, N. J.}


$\mathrm{U}$ removing them from the water, cut away broken or damaged roots. Take care not to expose the roots to sun, light, and wind.

The ground should be thoroughly prepared, breaking the subsoil. To do this, it is necessary to dig 15 to 18 inches deep and to mix a liberal supply of well-rotted manure or other fertilizer with the soil. A little air-slaked lime will help sweeten it.

Dig a hole large enough to accommodate the roots and spread them on the bottom of the hole, in the same position as you would place your hand on a flat surface. When filling in, lift and shake the plant lightly in order that the soil may sift between the roots, and after this operation, firm with the hands and feet. Be sure that the lower parts of the lower branches are at least 2 inches below the surface of the soil. (Picture No. 1.) Do not plant on a mound, the surface should be level, or a slight depression left around the plant. Cut back the branches within 2 to 4 inches of the surface of the ground, leaving the stronger branches 4 inches high above the soil. (Pictures 2 and 3.)

In cultivating Roses, the soil cannot be kept too tight at the roots and too loose on the surface during the growing season.

The branches of Climbing Roses should be cut back to 18 to 24 inches. A few flowers will develop the first year, by using this idea, although our method is to cut back the Climbers, when they are being transplanted in our Nursery, to within 2 to 4 inches of the main stem of the plant. Climbing Roses pruned this way will eventually give most satisfactory results.

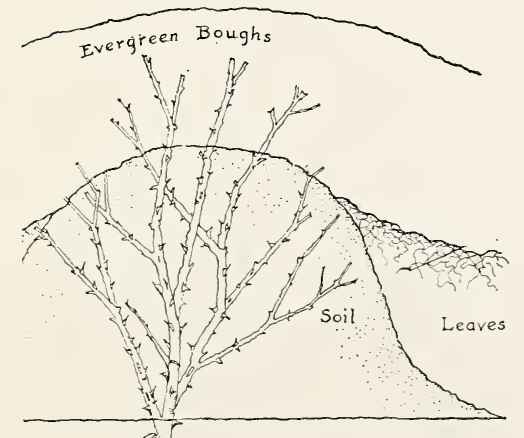

\section{Brief Suggestions For Planting Roses in the Spring} PON the arrival of the plants, open the bundle in a sheltered place and soak them thoroughly, or immerse the plants in a pail or tub of water for a few hours. After

In fall, just before cold weather sets in and frost enters

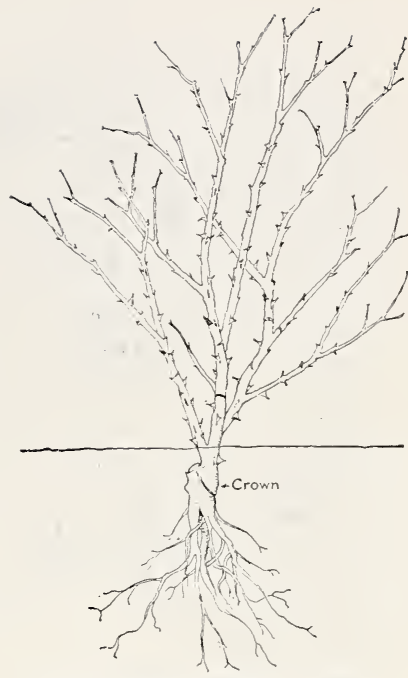

No. 1. Roses as received. Note depth to plant

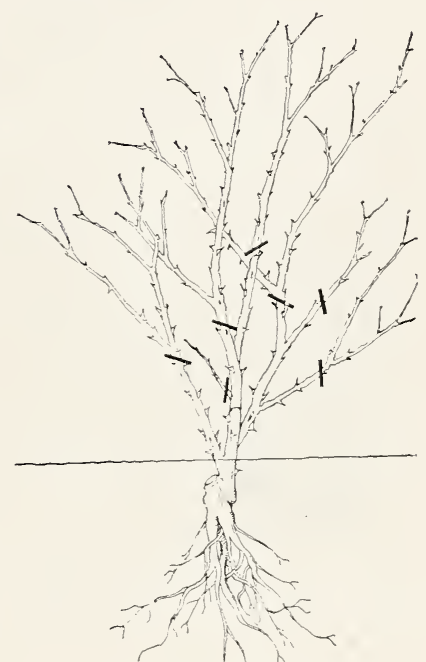

No. 2. Note where to prune the ground, mound the soil around the branches of the plant at least a foot high, and cover with a little meadow hay or some other loose litter. This will prevent the wind and sun from drying the branches during the winter. (Picture 4.)

Please keep in mind that these are planting suggestions, given to help the amateur, and we do not wish to be held responsible for results.

No. 4. Hilled up, pruned a bit and winter protection.
See "Roses by Bobbink \& Atkins" for other cultural suggestions.

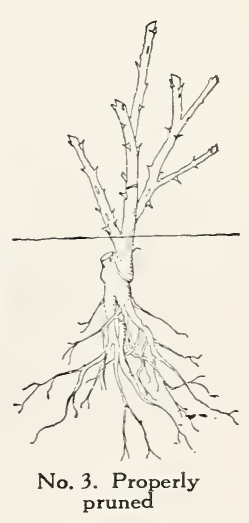




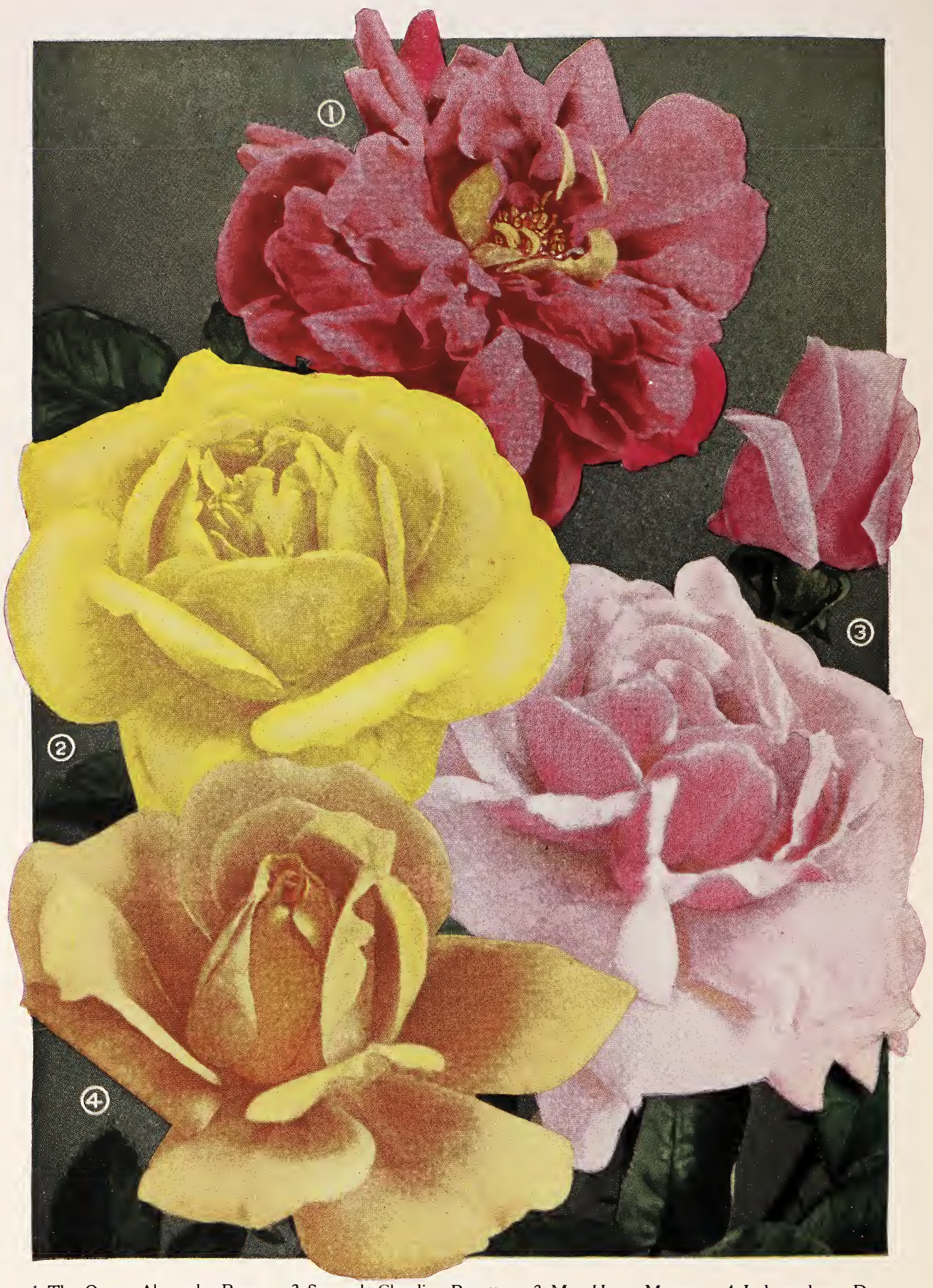

1 The Queen Alexandra Rose 2 Souv. de Claudius Pernet 3 Mrs. Henry Morse

4 Independence Day

This collection of 4 for $\$ 5 ; 12$ of these, your choice, $\$ 14$ 


\section{NOVELTIES AND NEW ROSES}

The following varieties have been chosen from the importations and American introductions of the past few years. They are all interesting, and most of them display color variations and combinations that are uncommon if not entirely different from older varieties. With the certainty of beauty and of grace they have the additional allure of the unknown, offering all the charms of an adventure in the realm of "something new and strange." We grow and have for sale hundreds of other varieties which will be found listed and described in "Roses by Bobbink \& Atkins" and its "Supplement."

\section{These varieties are $\$ 2.50$ each, except where noted}

ADMIRATION. HT. (S. McGredy \& Son, 1922.) Pointed buds of salmon-rose, and large, high-centered blooms of cream-white, heavily shaded with light orange-vermilion. Fragrant and fairly free-flowering. A vigorous, healthy plant.

BESSIE CHAPLIN. HT. (Chap'in Bros., 1921.) Large, globular buds and flowers of clear, bright pink, shaded darker at the base of the petals. A giant exhibition variety of great freedom of growth.

CAPTAIN RONALD CLERK. H'T. (S. McGredy \& Son, 1923.) Tapering, scarlet buds, opening to nearly single flowers of vivid scarlet-orange, with yellow at the base of the sharply reflexing petals. Fragrant, free-flowering, vigorous and bushy.

CECHOSLAVIA. HT. (V. Berger, 1921.) Tapering buds and large, double flowers of alabaster-white, with a goiden center and light red shading at the base of the petals. Fragrant and a good grower.

DAME EDITH HELEN. HT. (A. Dickson \& Sons, 1926.) Shapely buds and substantial, high-centered blooms of clear pink, sweetly scented and freely produced on long, strong stems. Vigorous and healthy. $\$ 3.50$ each.

FRAU FELIX TONNAR. HT. (M. Leenders \& Co., 1924.) Very large, tapering buds, opening to bright rose, semi-double blooms of substantial size, heavily shaded with orange and copper at the base of the petals. Very fragrant. Plant is vigorously bushy and profuse in bloom.

INNOCENCE. H'T. (Chaplin Bros., 1921.) Tapering; urn-shaped buds, opening to enormous, single, pure white blooms adorned with a giant center of wine-red stamens tipped with golden anthers. The plant is strong, branching, and healthy, flowering freely.

A marvelously handsome single Rose like a tremendous Japanese anemone. Even Rose-lovers who have little regard for single Roses have become enthusiastic over Innocence, comparing it very favorably with the exquisite beauty of Mermaid, whose slight tenderness to cold puts it to disadvantage in comparison with a hardy Rose like Innocence. Illustrated on front cover.

LADY DIXON-HARTLAND. H'T. (B. R. Cant \& Sons, 1923.) Buds pointed; flowers large, rich salmonpink, with lighter edges, and suffused throughout with orange-yellow; very fragrant. A vigorous grower and a prolific bloomer, especially in autumn.

LADY MARGARET STEWART. HT. (A. Dickson \& Sons, 1926.) A large exhibition bloom with enormous petals. It is of perfect form, with a high-pointed center. White, shaded buff and yellow. Not very fragrant. Foliage dark and free from disease. $\$ 3.50$ each.
LADY VEREY. HT. (E. J. Hicks, 1922.) Long, tapering buds of rich shell-pink, opening to rose-pink flowers which are rather thin. Of moderate growth.

LORD ALLENBY. HT. (A. Dickson \& Sons, 1923.) Ovoid buds and fine, massive, high-centered blooms, opening slowly to true globular form. Bright crimson with both dark and lighter shades and no fragrance. Dwarf, sturdy growth and foliage of fair quality.

MABEL PRENTICE. HT. (W. E. Lippiatt, 1923.) Orange-pink buds and very large flowers, showing tones of copper, orange, and yellow, opening clear rose-pink. Vigorous and free flowering.

MABEL TURNER. HT. (Hugh Dickson, 1923.) Long, pointed buds and conical flowers with high centers and very large, deep petals which are blushwhite on inner surface and rosy carmine on outside; faintly perfumed. Moderately vigorous.

MAUD CUMING. HT. (A. Dickson \& Sons, 1923.) Long, tapering buds and double, globular flowers of peach-pink with coral shadings and strong orange veins; only slightly fragrant. An abundant bloomer of vigorous, bushy growth, with healthy foliage.

MME. ALEXANDRE DREUX. HT. (Soupert \& Notting, 1921.) Intensely yellow bud, opening to a smallish, high-centered flower with sharply reflexed petals of deep yellow splashed with orange. Plant is moderately vigorous, wiry; fairly free flowering.

MRS. C. W. EDWARDS. HT. (S. McGredy \& Son, 1924.) Pointed buds and vivid, dark rose blooms of moderate size with a brilliant golden suffusion in the high-pointed center, giving a distinct coppery red effect. Strong, bushy and healthy. $\$ 1.50$ each.

MRS. HENRY BOWLES. HT. (Chaplin Bros., 1921.) Ovoid buds and globular flowers of clear, piercing pink with lighter shades. A fine firm center, well held, and fairly fragrant. Vigorous and free flowering. $\$ 1.50$ each.

MRS. T. J. ENGLISH. HT. (English \& Son, 1922.) Apricot and amber flowers, with petals curled and reflexed, showing salmon veins; fragrant. Stems long and stiff. Plant vigorous, with heavy foliage.

MURIEL WILSON. T. (Dr. J. Cainpbell-Hall, 1922.) Enormous, high-pointed blooms of lemon-white, borne on strong stems. Delicately fragrant. Vigorous growth and moderately free flowering.

PINK PEARL. HT. (M. Leenders \& Co., 1924.) Pointed buds and flowers with firm, high center, bright rose-pink, with yellowish salmon base; fragrant. Vigorous, healthy growth and steady blooming.

PRINCESS GHIKA. T. (P. Nabonnand, 1921.) Large, full flowers of elegant form, brilliant red with dark reflexes. Continuous blooming. 
REV. F. PAGE-ROBERTS. HT. (B. R. Cant \& Sons, 1921.) Copper-red buds of great length, opening to golden yellow blooms stained outside with red, fully double (40 to 50 petals) and very large; fragrant. Strong, branching plant with healthy foliage.

A supremely gorgeous Rose, developing to surpassing magnificence of size, color, and fragrance in the cool weeks of autumn. We believe it deserves great popularity. Not always at its best in hot weather but is superb in fall.

For that reason we are again placing it among the Novelties and reissuing the color-plate on the back cover which has been praised here and abroad as an unusually fair and just representation of its flowers. $\$ 2$.

RICHARD E. WEST. HT. (A. Dickson \& Son, 1924.) Long, pointed buds and high-centered, large flowers of light yellow, paling to lemon and lighter yellow; fragrant. Plant vigorous and free-flowering.

ROSABEL WALKER. HT. (F. Cant \& Co., 1922.) Long, tapered buds and very double, flat flowers of velvety crimson; moderate perfume. Very vigorous growth, free-flowering, and healthy.

ROSETTE DELIZY. T. (P. Nabonnand, 1921.) Small, slender buds and firm, high-centered flowers of heavy texture, pale yellowish pink with rosy outer petals. Free-flowering and vigorous.

SOUVENIR DE F. BOHÉ. HT. (C. Chambard, 1922.) Globular buds and flowers of very large size and intense orange-salmon; moderately fragrant. Vigorous, but not immune to mildew.
SOYECOURT. HT. (Jersey Nurseries, 1921.) Bloodred, overlaid orange-vermilion. Vigorous growth, flowering continuously.

SYBIL. HT. (Bees, Ltd., 1921.) Tapering buds and blooms of immense size, with heavy petals of silvery salmon shaded rose and orange, reflexed from an extremely high center. Plant moderately vigorous.

THE GENERAL. HT. (J. H. Pemberton, 1920.) Pointed buds and large, globular, high-centered flowers of rich velvet red, very lasting and intensely fragrant. Plant stocky, free-flowering and healthy.

TIM PAGE. HT. (Courtney Page, 1920.) Clusters of medium-sized flowers of pure daffodil-yellow which fades very little. Erect, vigorous with glossy foliage.

VESUVIUS. HT. (S. McGredy \& Son, 1923.) Long, tapering buds opening to very large, single flowers of dark, velvety crimson. It is moderately fragrant and flowers with especial freedom in the fall. A single Rose remarkable for the rich, dark color so rare in that type.

WALTHAM FLAME. HT. (W. Paul \& Son, 1921.) Rich terra-cotta flowers, shaded with bronzy orange. Free-flowering and recommended for bedding.

WILHELM KORDES. HT. (W. Kordes Söhne, 1922.) Long, pointed buds and double, high-centered flowers of deep golden yellow, overspread with a tint of copper, and striped with red. Very fragrant and unusually free-flowering. Vigorous, compact growth. $\$ 3$ each.

\section{ADDITIONAL ROSES}

This section comprises Roses of recent date and some older sorts which in general are too little known by Rose-lovers.

ADONIS. HT. Ivory-cream, lightly shaded with lemon. $\$ 1.50$ each.

ALADDIN. HT. Copper-yellow. \$1 each.

ARGENTINE CRAMON. HT. Shading from pure white to rose, with salmon center. \$1 each.

ARIEL. HT. Flowers orange-flame and yellow. $\$ 1.50$ each.

ASPIRANT MARCEL ROUYER. HT. Bronzy apricot, paling to salmon at edges. \$2 each.

BETTY UPRICHARD. HT. Copper-red and orangecarmine. $\$ 1.50$ each.

CAPTAIN F. BALD. HT. Velvety crimson. $\$ 1.50$ ea

CAPTAIN KILBEE-STUART. HT. Dark crimson, shaded with vermilion. $\$ 1.50$ each.

COMTE G. DE ROCHEMUR. HT. Bright scarlet and vermilion. $\$ 1$ each.

COMTESSE DU CAYLA. China Rose. Coppery pink, with orange shades. $\$ 1$ each.

C. V. HAWORTH. HT. Blackish scarlet. \$1 each.

DIADEM. HT. Copper-orange with salmon tint. $\$ 1.50$ each.

DIANA. HT. Silvery flesh-color. $\$ 1.50$ each.

DOMKAPITULAR DR. LAGER. HT. Salmon-pink and carmine. $\$ 1.50$ each.

ELEGANTE. HT. Creamy yellow. $\$ 1.50$ each.

ELSIE BECKWITH. HT. Rich deep glowing rosy pink. $\$ 1.50$ each.

EMILE CHARLES. HT. Coral-red with flame-colored base. $\$ 1.50$ each.

EMMELINE. HT. Flowers lemon-yellow. \$2 each.
E. P. H. KINGMA. HT. Deep apricot and orangeyellow. $\$ 1.50$ each.

ETHEL DICKSON. HT. Deep salmon-rose, with silvery reflex. $\$ 1$ each.

ETHEL SOMERSET. HT. Coral and shrimp-pink. $\$ 1.50$ each.

ETIENNE REBEILLARD. HT. Flesh-pink. \$1.50 each.

FELICITY. HT. Mallow-pink, shaded cerise and cream. $\$ 1.50$ each.

FEU JOSEPH LOOYMANS. HT. Yellow with vivid apricot tints. $\$ 1.50$ each.

FLAMMENROSE. Per. Orange-yellow. $\$ 1.50$ each.

FRAU DR. KRUGER. HT. Creamy salmon. \$1 each.

GEISHA. HT. Orange-yellow, changing to golden yellow. \$1 each.

HELENE DUCHE. HT. Soft rose with silvery reflexes. $\$ 2$ each.

HERFSTOOI. HT. Bright purplish red blooms. $\$ 1.50$ each.

HORTULANUS BUDDE. HT. Dark red with yellow center. $\$ 1.50$ each.

HORTULANUS FIET. HT. Deep ochre-yellow $\$ 1.50$ each.

IMPERIAL POTENTATE. HT. Dark shining rosepink. $\$ 1.50$ each.

INDEPENDENCE DAY. HT. Flaming yellow, fading to light orange-pink. $\$ 1.50$ each.

JEAN C. N. FORESTIER. HT. Reddish buds opening carmine, orange, and yellow. $\$ 1.50$ each.

JOHANNES TROJAN. HT. Crimson. \$1 each. 
LADY CRAIG. HT. Creamy blooms tinted yellow in center. $\$ 1.50$ each.

LOUISE JOLY. Per. Flowers capucine-lake, shaded reddish salmon and orange-yellow. $\$ 2$ each.

LULU. HT. Orange-pink and copper. $\$ 1$ each.

MABEL MORSE. HT. Clear yellow. $\$ 1.50$ each.

MISS AMELIA GUDE. H'T. Deep ycllow center, shading to cream. $\$ 1.50$ each.

MME. ANTOINE MARI. T. Flesh-color, with lilac and rose shadings. \$1 each.

MME. JULIEN POTIN. ITT. Flesh-pink. \$1 each.

MME. POINCARE. HT. Pale pink and salmon. $\$ 1$ each.

MORGENGLANS. HT. Flowers salmon-flesh. $\$ 1 . \tilde{0}$ each.

MRS. DAVID MCKEE. HT. Amber-white, changing to sulphury white. $\$ 1$ each.

MRS. HENRY MORSE. HT. Two contrasting tones of pink, with yellow glow. $\$ 1$ each.

MRS. HENRY WINNETT. H'T. Rich-red. \$1 each.

MRS. JAMES WILLIAMSON. HT. Clear shellpink. $\$ 1.50$ each.

MRS. J. C. AINSWORTH. HT. Pale pink, shaded mauve and white. \$1 each.

MRS. PRENTISS NICHOLS. HT. Dark pink. $\$ 1$ each.

MRS. RAMON DE ESCOFET. HT. Intense crimsonflame. \$1 each.

MRS. WILLIAI C. EGAIN. HT. Deep flesh-color, and a golden glow at base of petals. $\$ 1.50$ each.

MRS. WILLIAM SERGENT. HT. Apricot and peach. $\$ 1.50$ each.

PADRE. HT. Copper-scarlet, bright yellow at base of petals. $\$ 1.50$ each.

PAX LABOR. HT. Pale yellow with deeper center. $\$ 1.50$ each.

PRESIDENT CHERIOUX. HT. Salmon-pink, with redidish bufi shading. $\$ 1$ each.
RED PREMIER. HT. Velvety red, reverse carminered. $\$ 1.50$ each.

ROBERT HUEY. HT. Carmine-red. \$1 each.

SECRETARIS ZWART. H'T. Bright rose and salmon. $\$ 1.50$ each.

SERGE BASSET. HT. Deep garnet-red. \$1 each.

SHOT SILK. HT. Coppery rose, flushed with apricot and yellow. $\$ 1.50$ each.

SLVER COLUMBIA. HT. Pale silvery pink. \$1.50. SOUVENIR DE CLAUDIUS DENOYEL. HT. Crimson-red, tinted vermilion. $\$ 1$ each.

SOUVENIR DE CLAUDIUS PERNET. HT. Yellow, paling somewhat toward the edge. $\$ 1.50$ each.

SOUVENIR DE GABRIEL LUIZET. HT. Sulphuryellow, changing to straw-yellow when opened. $\$ 2$ each.

SOUVENIR DE GEORGE BECKWITH. HT. Salmon-pink and yellow. $\$ 1.50$ each.

SOUVENIR DE GEORGES PERNET. HT. Terracotta-pink. $\$ 1.50$ each.

SOUVENIR DE MARQUES LOUREIRO. HT. Light red, shading to rosc, with yellow and purple tints. $\$ 1.50$ each.

SOUVENIR DE MME. BOULLET. HT. Dark yellow. $\$ 2$ each.

SUBSTITUT JACQUES CHAPEL. H'T. Peachblossom color, shaded lemon-yellow at base. $\$ 2$ each.

SUNNY JERSEY. HT. Bronzy salmon and orange. $\$ 1.50$ each.

SUNSTAR. HT. Deep orange and yellow, splashed crimson and vermilion. $\$ 1.50$ each.

THE QUEEN ALEXANDRA ROSE. HT. Scarlet on inside and yellow on outside of petals. $\$ 1.50$ each.

UNA WALLACE. HT. Luminous old-rose color. $\$ 1$ each.

VENUS. HT. Light pink, toning to pale flesh or cream at edges of petals. $\$ 1.50$ each.

WESTFIELD STAR. HT. Lemon-yellow. \$2 each.

\section{NOVELTY CLIMBING ROSES}

\section{Introduced 1926 by Bobbink \& Atkins}

The four varieties offered below and on page 10, and pictured in color on the following two pages, were originated by F. R. M. Undritz, of West New Brighton, N. Y., within the past ten years but for various reasons have not been actually put in commerce, although there has been much interest and curiosity about them, carrying forward, as they do, the remarkable climbing strain originated by the late Dr. W. Van Fleet, through two of his choicest varieties, Silver Moon and Dr. W. Van Fleet. We consider them worthy additions to this high-grade class of Climbing Roses and are glad that we are first to make them available for general planting.

\section{These Novelties are $\$ 2.50$ each}

BEN STAD. HW. (F. R. M. Undritz, 1926.) Mediumsized, ovoid buds and informal, cupped flowers of creamy white, flushed with flesh-pink on the back and illumined by large golden centers, fragrant and lasting, borne in sprays on long, strong stems. Plant is very vigorous, of climbing habit, and blooms profusely for three to four weeks. Foliage dark green, glossy, and resistant to disease.

This Rose was registered with the American Rose Society in 1925 as Rev. Floris Ferwerda, but because of the difficulty of remembering and pronouncing that name it was given a new one. Undoubtedly one of the most charming climbers recently introduced.
FREEDOM. HW. (F. R. M. Undritz, 1918.) Medium-sized, oval buds and full, cupped flowers of pure white tinged with lemon in the center and slightly fragrant, borne several together on long strong stems. Plant of vigorous climbing habit with leathery foliage. It blooms very freely over a long period beginning in June.

A cross between Silver Moon and Kaiserin Auguste Viktoria, approaching Silver Moon in habit and Kaiserin in flower. We have found it a most handsome white elimber of great refinement and charm, and are sure it will be well liked when it becomes established. 


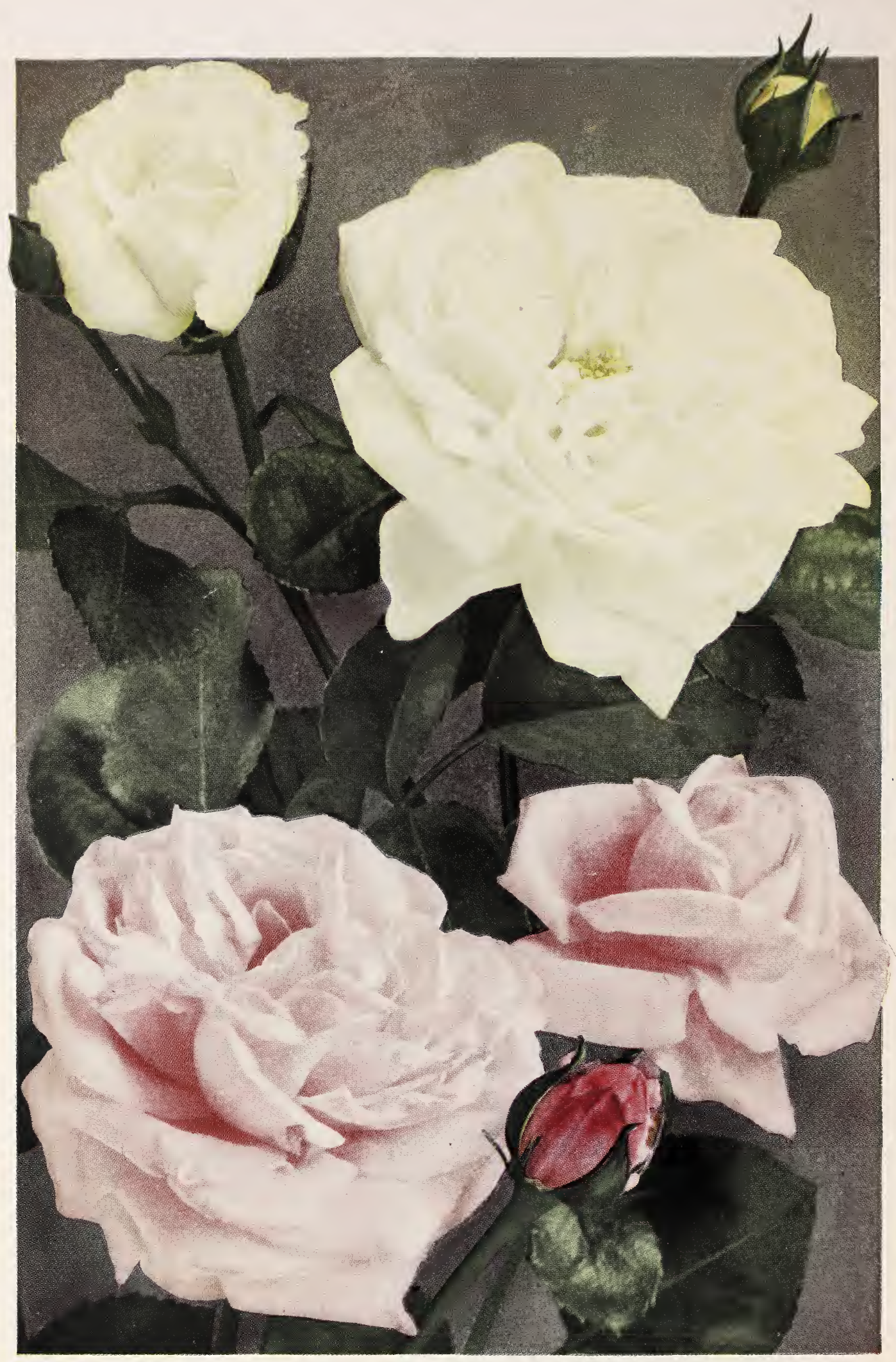

Freedom (above) and General John Pershing (below). See descriptions on pages 7 and 10 


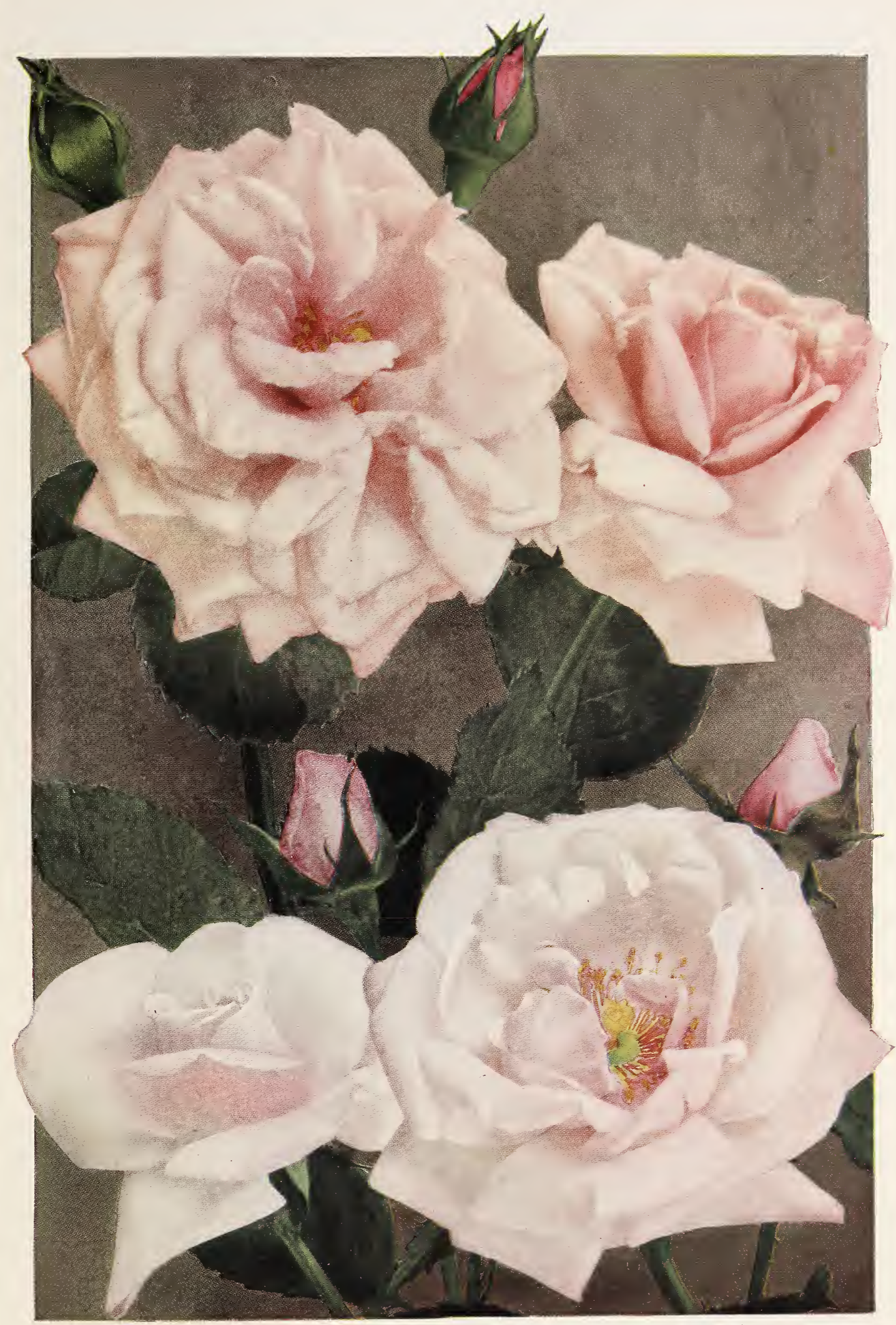

Victory (above) and Ben Stad (below). See descriptions on pages 7 and 10 
GENERAL JOHN PERSHING. HW. (F. R. M. Undritz, 1920.) Dark pink, almost red, buds opening to double, medium-sized, pointed flowers of brilliant dark pink; mildly fragrant, and borne on strong stems of medium length. Growth is vigorously climbing with dark green, glossy foliage.

A cross between Dr. W. Van Fleet and Mrs. W. J. Grant. It was first called F. R. M. Undritz, under which name it was registered with the American Rose Society in 1917; but later it was renamed with the permission of the Society. The flowers are doubler than Dr. W. Van Fleet and at times resemble La France. We have found it a remarkably vigorous grower producing great quantities of high-grade flowers.
VICTORY. HW. (F. R. M. Undritz, 1918.) Pointed buds and exquisite, medium-sized flowers of salmonpink a shade or two lighter than General John Pershing. Moderately fragrant and borne in sprays on strong stems suitable for cutting. A fairly strong climber with glossy, healthy foliage not easily afflicted with common rose troubles.

A cross between Dr. W. Van Fleet and Mme. Jules Grolez which has shown genuine quality as a low climber or Pillar Rose. Its growth is not as rampant as others of this class which is an advantage in gardens of restricted space. The flowers are lasting and the blooming season endures for several weeks in early summer. This is the most delicately colored of the four, and we believe it will become popular.

\section{ADDITIONAL VARIETIES OF CLIMBING ROSES}

This section includes desirable Climbers of several types. Our stocks of these varieties were too limited to offer them in "Roses by Bobbink \& Atkins" when it was published.

ALBERTINE. HW. Coppery chamois-yellow flowers, passing to coppery rose. $\$ 1$ each.

CORALIE. HW. Orange-salmon flowers, paling to soft pink. \$1 each.

DR. HUEY. HW. Crimson-maroon, shaded black. 75 cts. each.

EMIIY GRAY. HW. Large, semi-double, deep golden buff flowers, practically unfading and slightly fragrant, produced singly or in small clusters by a strong-growing plant, bearing wonderfully pointed and polished holly-like foliage. $\$ 1$ each.

HEART OF GOLD. HW. Dark purplish crimson, with a white center and showy golden stamens. $\$ 2$ each.

HUGUETTE DESPINEY. HW. Greenish white buds, tipped with red and rose. $\$ 1$ each.

IIE DE FRANCE. HW. Light crimson flowers, with white centers and clusters of sparkling golden stamens. $\$ 1.50$ each.
JACOTTE. HW. Orange-yellow, tinted copper-red. \$1.

MARY WALLACE. HW. Very bright pink flowers illumined with shining gold. $\$ 1$ each.

MERMAID. H.Brac. Pure ivory-white, with cream and lemon center. $\$ 1.50$ each.

MME. VICTOR LOTTIN. HW. Lovely dark red flowers with crimson shadings. $\$ 1$ each.

PAPA ROUILLARD. HW. Bright carmine. $\$ 1.50$ ea. PETIT LOUIS. HW. Double flowers of salmon-rose, with silvery tints. $\$ 1$ each.

ROMEO. HW. Fine, perfect buds and flowers of light, sparkling crimson. $\$ 1$ each.

SOUVENIR DE L'AVIATEUR METIVIER. HW. Yellow in bud, almost white when expanded. \$1 ea.

STAR OF PERSIA. H. Foet. Semi-double bright yellow flowers about 3 inches across. $\$ 1.50$ each.

THE BEACON. HW. Bright fiery red, with white eye. $\$ 1$ each.

\section{POLYANTHAS}

A selection of rare and unusual varieties of the favorite edging and bedding type of Rose. ENNCHEN MÜLLER. Shining bright pink. 75 cts. each.

ALICE AMOS. Large; bright cherry-pink. \$1.50 each. BÉBÉ BLANC. Pure white; double. $\$ 1.50$ each.

CORAL CLUSTER. Pale coral-pink. \$1 each.

EBLOUISSANT. Glowing dark-red. \$1 each.

EVELYN THORNTON. Pale pink and gold. $75 \mathrm{cts}$. each.

FRAU DR. ERRETH. Deep golden yellow buds, shading to cream upon opening. 75 cts. each.

FRAU R. SCHMIDT. Garnet-red. \$1 each.

GRUSS AN AACHEN. Flesh-pink and salmon-yellow flowers; very large and double. 75 cts. each.

HELEN LEENDERS. Light pink. \$1.50 each.

LA ROSEE. Tender pink. \$1 each.

LADY READING. Bright red, very beautiful. \$1 each. MARTHA. Soft pink. $\$ 1.50$ each.

MRS. WM. G. KONING. Pure white. 75 cts. each. ORANGE KING. Brilliant orange. $\$ 1.50$ each.

RÖDHÄTTE. Light shining crimson. 75 cts. each.

RUDOLF KLUIS. Vermilion buds and flowers. $\$ 1$ ea.

VULCAIN. Dark carmine-red. \$1 each.

\section{NEW DR. W. VAN FLEET ROSES}

DR. E. M. MILLS. Hybrid Hugonis. (Dr. W. Van Fleet, 1926.) An early-blooming, spreading shrub Rose, 3 to 4 feet high, similar to the graceful Scotch roses in its habit and in its manner of spreading by underground rootstocks. Foliage is small and deep green, and the new growth is almost thornless, with sharp, straight thorns on the mature wood. Flowers are medium size ( 2 to $21 / 2$ inches across), semi-double, peculiarly globular in shape, and profusely produced along and around the arching branches. They are primrose color, with a pink suffusion which becomes more pronounced in the later blooms. \$2 each.

SARAH VAN FLEET. Hybrid Rugosa. (Dr. W. Van Fleet, 1926.) The plant is of erect and spreading habit, with medium green Rugosa-type foliage. It is a vigorous grower, very hardy, with flowers having three to four rows of petals, opens flat, shows stamens; color, mild rose-pink; form, cupped; fragrance, moderate; bud, medium size; petalage twenty to thirty; freedom of bloom and lasting quality, excellent. The rose is distinct from all the Rugosa hybrids in purity of color and continuity of flowering, and is considered as a decided improvement in the race. $\$ 2$ each. 


\section{Rutherford, N. J. Standard or Tree Roses}

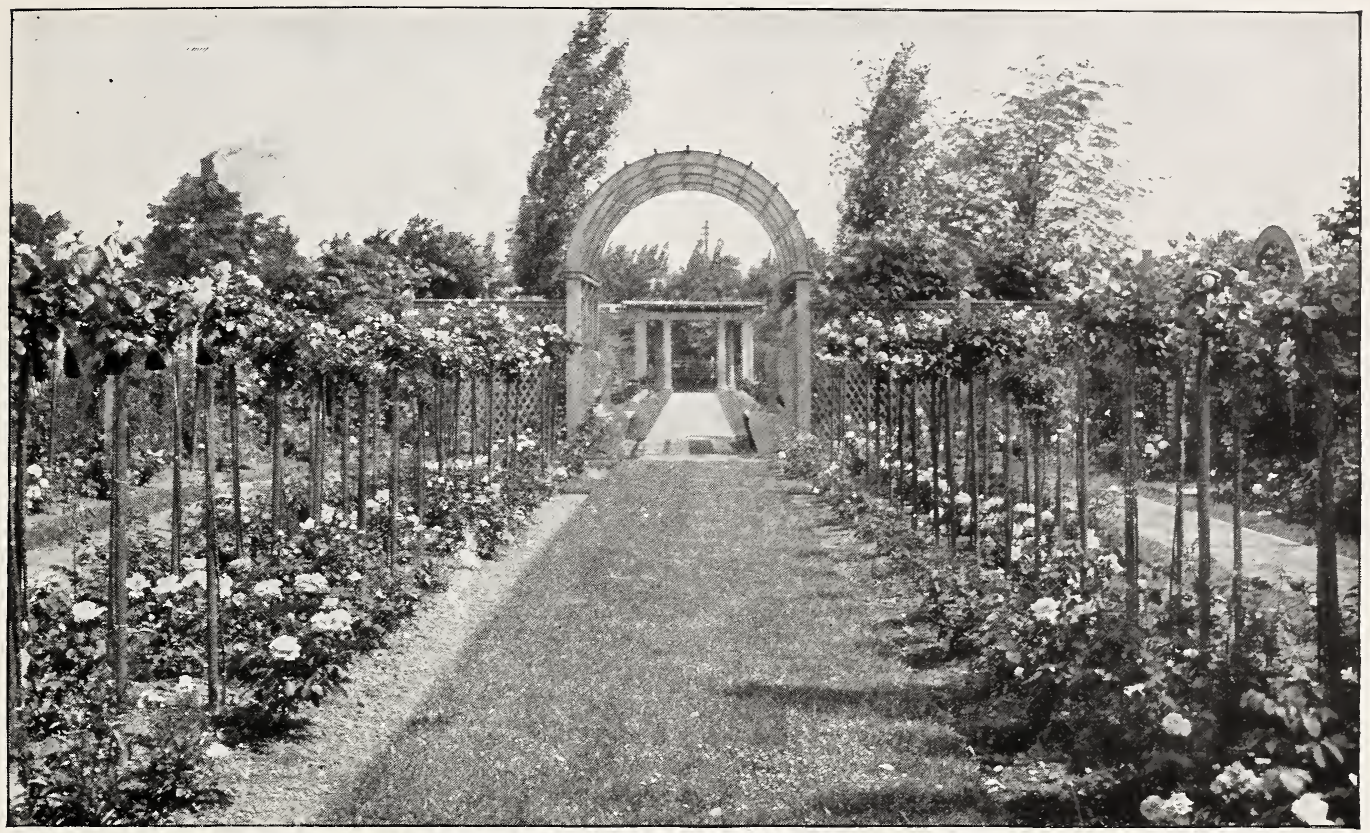

\section{STANDARD OR TREE ROSES}

These ornamental Tree Roses relieve the flat appearance in the Rose-garden and allow the use of a larger number of varieties in gardens of limited space. They are less susceptible to mildew and black-spot, and many of the Pernetiana type do better on Standards for this reason. A stake on the sunny side will act as support and protection from hot sun.

For winter protection of Standard Roses, ask for directions.

$$
\$ 3.50 \text { each, } \$ 30 \text { for } 10
$$

Betty

Capt. Hayward

Charles K. Douglas

Constance

Crimson Queen

Duchess of Wellington

Edel

Eldorado

Elli Hartmann

Etoile de Feu

Etoile de Hollande

Frau Karl Druschki

General MacArthur

General-Superior Arnold Janssen

George C. Waud

George Dickson

Golden Emblem

Golden Ophelia

Gruss an Aachen

Gruss an Teplitz
Independence Day
Janet
Kaiserin Auguste Viktoria
La Tosca
Lady Alice Stanley
Lady Ashtown
Lady Hillingdon
Lady Pirrie
Los Angeles
Louise C. Breslau
Miss Cynthia Forde
Miss Lolita Armour
Mme. Bardou Job
Mme. Butterfly
Mme. Caroline Testout
Mme. Edouard Herriot
Mme. Leon Pain
Mrs. Aaron Ward

Mrs. Ambrose Ricardo

Mrs. A. R. Waddell

Mrs. Henry Morse

Mrs. John Laing

Mrs. W. C. Miller

Old Gold

Ophelia

Radiance

Red Radiance

Red Star

Rev. F. Page-Roberts

Souv. de Claudius Pernet

Souv. de Georges Pernet

The Queen Alexandra Rose

Ulrich Brunner

Una Wallace

Westfield Star

William R. Smith

\section{HIGH STANDARD ROSES}

We have a limited quantity of these 5 to 6 feet high, climbing varieties only, at $\$ 5$ each, and shall be pleased to submit a list upon application. 


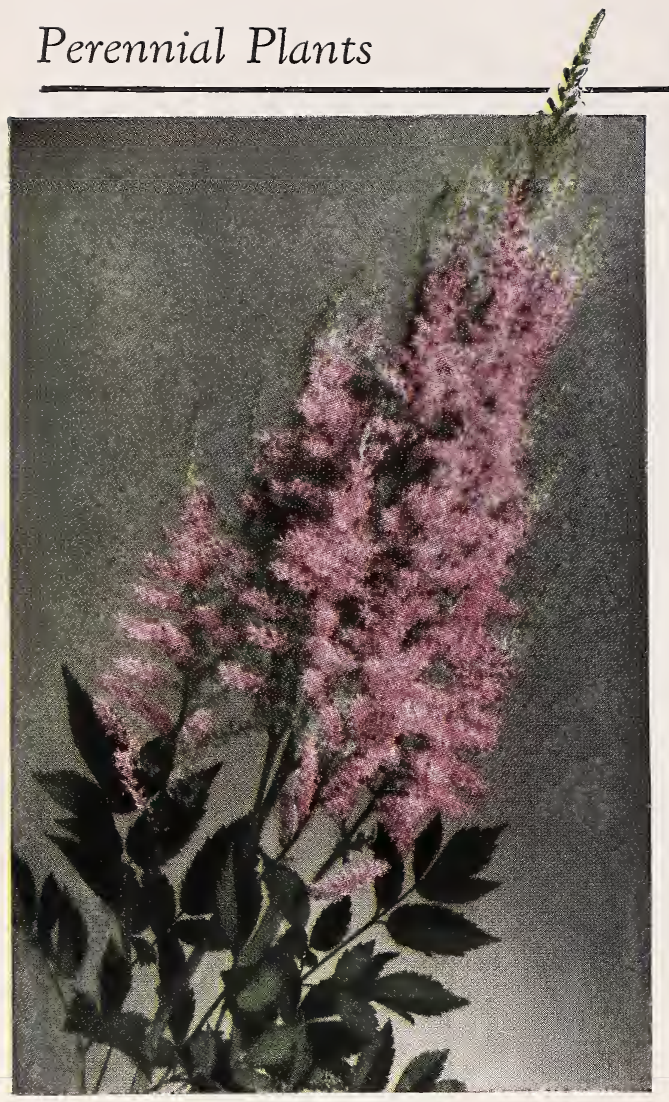

Astilbe, Gloria

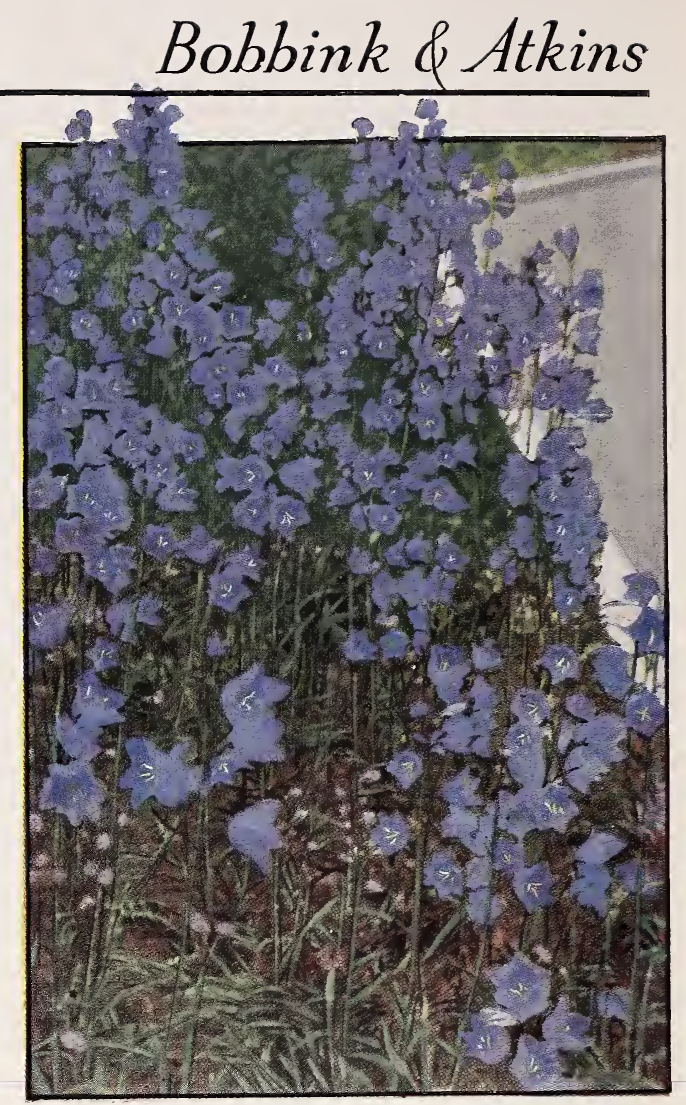

Campanula persicifolia, Telham Beauty

\section{PERENNIAL PLANTS}

\section{Novelties and Scarce Varieties}

By this term is meant such plants as may be allowed to remain permanently in the open ground, whose foliage dies down to or near the ground each autumn, coming forth again with renewed vigor the following spring, giving a continuation of bloom from early spring until frost. Other varieties listed in our "Hardy Herbaceous Plants" Catalogue.

ACONITUM autumnale. Autumn Monkshood. Flowers blue; late flowering. Sept.-Nov. 3 to $5 \mathrm{ft}$. 35 cts. each, $\$ 3$ for 10 .

AINCHUSA, Picotee. New. Blue and white. $50 \mathrm{cts}$. each, $\$ 4.50$ for 10 .

ANEMONE japonica Kriemhilde. Deep reddish rose, semi-double flower. 2 to $3 \mathrm{ft}$. Sept., Oct. $35 \mathrm{cts}$. each, $\$ 2.20$ for 10.

*ANTHERICUM (Paradisea) Liliastrum major. St. Bruno's Lily. Flowers white, with narrow, grasslike foliage; also good for cutting. $1 \frac{1}{2} \mathrm{ft}$. May, June. 35 cts. each, $\$ 3$ for 10 , $\$ 25$ per 100 .

AQUILEGIA alpina. True Alpine Columbine. Blue and white flowers, short spurs. Very good for rockery. About 1 foot. 30 cts. each, $\$ 2.20$ for 10 .

ARTEMISIA Purshiana. Woolly white-leaved variety with white flowers. 2 to $3 \mathrm{ft}$. Summer. 35 cts. each, $\$ 3$ for 10.

ASTER alpinus, Nancy Perry. New. An improvement on Aster alpinus with flowers very light blue, larger, and more round. Blooms freely in May and June. 30 cts. each, $\$ 2.20$ for $10, \$ 18$ per 100 .

Amellus. Large bluish lavender flowers, mixed. A very fine plant for the border and very attractive. $1 \frac{1}{2}$ to $2 \mathrm{ft}$. $50 \mathrm{cts}$. each, $\$ 4.50$ for 10 .
Aster amellus, Lutetia. New. Low-growing; large lilac-rose flowers. Very nice for border. About $2 \mathrm{ft}$. Summer. 35 cts. each, $\$ 3$ for 10.

Cordifolius, Star-Shower. New. Branching habit with fine small white flowers. 3 to $4 \mathrm{ft}$. Sept., Oct. Good for cutting, especially to use as filling material in bouquets, like gypsophila. $50 \mathrm{cts}$. each, $\$ 4.50$ for 10 .

Goldflake. Interesting on account of its color. Small, yellow flowers. $3 \mathrm{ft}$. Sept., Oct. 35 cts. each, $\$ 3$ for 10 .

Novæ-angliæ, Barr's Pink. New. One of the best pinks in the market, similar to Lil Fardel or Ryecroft Pink, but flowers larger. 4 to $5 \mathrm{ft}$. Sept., Oct. 75 cts. each, $\$ 7$ for 10 .

Novi-belgi, Brussel. Large, single flowers of pale lavender. Vigorous habit. A good variety. $4 \mathrm{ft}$. Sept., Oct. 25 cts. each, $\$ 2$ for 10.

-, Capitaine. Good-sized, light lavender-blue flowers. 4 to $4 \frac{1}{2} \mathrm{ft}$. Sept., Oct. $25 \mathrm{cts}$. each, $\$ 2$ for 10.

- Lady Grey. An exquisite shade of opal-grey with large, semi-double flowers. Very beautiful. 3 to 4 $\mathrm{ft}$. Sept., Oct. $50 \mathrm{cts}$. each, $\$ 4.50$ for 10 .

-, Mme. Carroy. New. A very good variety with large bluish lavender flowers. $3 \mathrm{ft}$. Sept., Oct. 50 cts. each, $\$ 4.50$ for 10 . 




Aconitum

Aster Novi-belgi, N. B. Mons. Large, deep rosecolored flowers, with stout branching stems. Very good. $3 \mathrm{ft}$. $25 \mathrm{cts}$. each, $\$ 2$ for 10 .

-, October Dawn. New. Large flowers of a pretty shade of lilac and mauve. Pyramidal growth. $2 \mathrm{ft}$. 50 cts. each, $\$ 4.50$ for 10 .

ASTHBE, Blush Pink. Light pink flowers. About $1 \frac{1}{2} \mathrm{ft}$. tall. June, July. 50 cts. each, $\$ 4.50$ for 10.

Gloria. Conspicuously beautiful with its dense, feathery plumes of brilliant dark pink flowers, shaded lilac. 75 cts. each, $\$ 6.50$ for 10 .

BUDDLEIA veitchi. Reddish-violet, delicately scented. 50 cts. each, $\$ 4.50$ for 10 .

CAMPANULA persicifolia Backhousei. Handsome white flowers with stout stems. A very good white variety. 2 to $2 \frac{1}{2} \mathrm{ft}$. June, July. $35 \mathrm{cts}$. each, $\$ 3$ for 10.

-, Telham Beauty. One of the best Persicifolia hybrids with very large, single, blue flowers. Very beautiful. $2 \frac{1}{2} \mathrm{ft}$. June, July. 50c. ea., $\$ 4.50$ for 10 .

-, Lavender Queen. Large flowers of lovely lavender-blue. 2 to $21 / 2 \mathrm{ft}$. June, July. $50 \mathrm{cts}$. each, $\$ 4.50$ for 10.

DIGITALIS Isabellina. New. Spikes of sulphur-yellow flowers. The nearest to a yellow Foxglove. June, July. 35 cts. each, $\$ 3$ for 10.

ERICA Tetralix Mackayi. Soft pink flowers. More prostrate grower than E. tetralix. Fine leaves. $50 \mathrm{cts}$. each, $\$ 4.50$ for 10 .

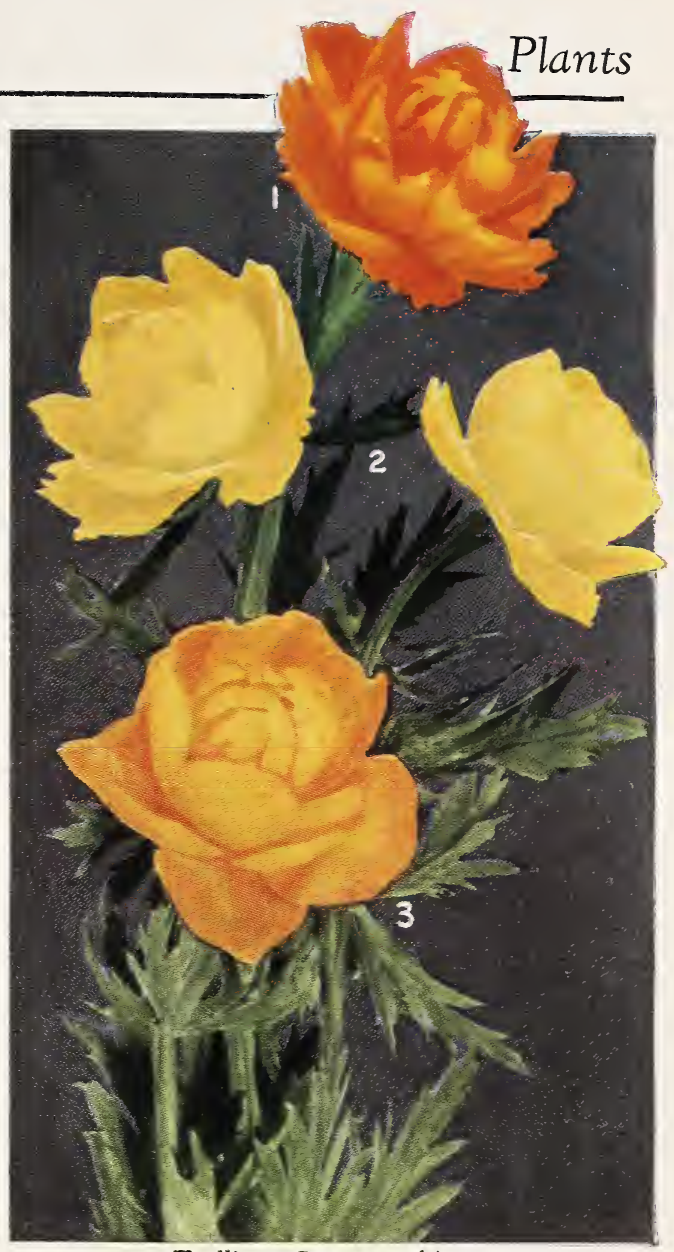

Trollius. See page 14

1 Orange Princess 2 Canary Bird 3 Japonicus fl.-pl.

ERIGERON glaucus. Taries in color from pale lavender to purple. $1 \frac{1}{2} \mathrm{ft}$. July, Aug. $35 \mathrm{cts}$. each, $\$ 3$ for 10.

ERYNGIUM aquaticum (yuccæfolium). Heads of white flowers. Yucca-like foliage. $2 \frac{1}{2}$ to $3 \mathrm{ft}$. 35 cts. each, $\$ 3$ for 10 .

GEUM, Lady Hillingdon. New. Large, golden yellow flowers, produced very freely all summer. $1 \mathrm{ft}$. 50 cts. each, $\$ 4.50$ for 10 .

HELENIUM, Bronze Queen. Bronze-yellow flowers. Spreading bush. Good for cutting. $4 \mathrm{ft}$. 30 cts. each, $\$ 2.20$ for 10 .

HELIANTHEMUM, Orange, Double. Rock-rose. Double orange flowers. Fine for rockery. $1 \mathrm{ft}$. June, July. 35 cts. each, $\$ 3$ for 10.

HELIANTHUS Ligeri. Light yellow flowers. 4 to 5 ft. Aug., Sept. 25 cts. each, $\$ 2$ for 10 .

Miss Mellish. Flowers rich golden yellow, produced in greatest profusion. 4 to $5 \mathrm{ft}$. Aug., Sept. 25 cts. each, $\$ 2$ for 10.

HEUCHERA brizoides gracillima. Very strong grower. Distinctive foliage. Flower-stems about $2 \frac{1}{2}$ foot tall, with medium-size creamy white blooms; brownish pink at edges. 35 cts. each, $\$ 3$ for 10 .

Walker's Variety. New. Very striking red bells similar to Flambeau, but a shade darker. An excellent variety. 50 cts. each, $\$ 4.50$ for 10 .

Mixed Colors. Good-sized plants from seedlings and cuttings. $35 \mathrm{ct}$. each, $\$ 3$ for 10. 
INULA Royleana (macrocephala). Ornamental foliage. Spikes of yellow flowers. Midsummer flowering. 25 cts. each, $\$ 2$ for 10.

IRIS, Dalmarius. S. pale gray-blue; F. darker, shaded violet-brown. 22 in. 25 cts. each, $\$ 2$ for 10.

Isola. S. light blue; F. violet-purple. A charming free-flowering variety. 30 in. 25c. each, $\$ 2$ for 10.

La Neige. Pure glistening white. 27 in. 50 cts. each.

Lent A. Williamson. S. lavender-violet; F. velvety pansy-purple. One of the best. 42 in. 75 cts. each.

Montezuma. S. deep golden yellow, dotted with brown; F. yellow and white, veined purple and dotted brown. Striking. $50 \mathrm{cts}$. each.

Pallida folia argentea variegata. Handsome foliage; variegated silver and white. $\$ 1$ each.

-folia aurea variegata. Handsome, golden variegated foliage. Rare. $\$ 1$ each.

Parisiana. S. white, dotted and shaded lilac-purple; F. white, with lilac edging. Fine large flower. 30 in. 35 cts. each.

Red Cloud. S. rosy lavender-bronze; F. maroon with yellow veins; stigmas old-gold. Dwarf. 50 cts. each.

Seminole. S. violet-rose; F. rich velvety crimson; distinct orange beard. 22 in. 75 cts. each.

ISATIS glauca. Good border plant with glabrous foliage and yellow flowers that are good for cutting. 2 to $4 \mathrm{ft}$. July. $25 \mathrm{cts}$. each, $\$ 2$ for 10.

JASIONE perennis. Shepherd's Scabious. Bright blue flowers similar to Scabiosa. July, Aug. 11/2 ft. 35 cts. each, $\$ 3$ for 10.

LAMIUM maculatum. A variegated Nettle, with deep purple flowers. $10 \mathrm{in}$. July, Aug. 50 cts. each, $\$ 4.50$ for 10 .

LAVANDULA, Munstead's Variety. New. This new Lavandula is quite an improvement over the old one, being more decorative and a much better grower. 35 cts. each, $\$ 3$ for 10.

LYTHRUM, Lady Sackville. New. Spikes of brilliant rose-pink flowers; very attractive and fine for cutting. A great improvement over all the other varieties. Aug., Sept. $2 \frac{1}{2} \mathrm{ft} .50$ cts. each, $\$ 4.50$ for 10 .

MEGASEA, Distinction. Rosy purple flowers. $50 \mathrm{cts}$ each, $\$ 4.50$ for 10 .

Giant. Immense foliage; purple flowers. 50 cts. each, $\$ 4.50$ for 10 .

NEPETA Okranica. Does not differ much from $N$. Mussini, but is somewhat taller grower, with mauve-colored flowers. $1 \mathrm{ft}$. April-June. $25 \mathrm{cts}$. each, $\$ 2$ for 10.

CENOTHERA Fraseri. A dwarf plant with brownish green foliage and yellow flowers. $2 \mathrm{ft}$. About July. 25 cts. each, $\$ 2$ for 10.

Glabra. The bright yellow flowers contrast beautifully with the bright reddish brown foliage. $2 \mathrm{ft}$. June, July. 25 cts. each, $\$ 2$ for 10.

PÆONIA, Dorothea. A very good, red, single-flowering Peony. 75 cts. each.

PAPAVER alpinum. Alpine Poppy. This beautiful Alpine plant blooms profusely all summer in all bright colors. It is excellent for the rockery. $8 \mathrm{in}$. 75 cts. each, $\$ 7$ for 10.

Bracteatum. Extremely large, blood-red flowers, shaded orange. Very strong grower. June, July, 35 cts. each, $\$ 3$ for 10.

Orientale, Goliath. Large, open, cup-shaped flowers of glowing bright scarlet, with a few distinct blotches. Very good grower. Excellent. 35 cts. each, $\$ 3$ for 10 .

-, Goldschmidt. Medium-sized, orange-scarlet flower. 35 cts. each, $\$ 3$ for 10.
Papaver orientale, Good. Dark red flowers. $35 \mathrm{cts}$. each, $\$ 3$ for 10 .

-, Grand Mogul. Very good grower. Deep red blooms with big blotches. 35 cts. each, $\$ 3$ for 10 . -, Orange Queen. Strong grower. Flowers orangescarlet, with prominent blotches. 35c. ea,, $\$ 3$ for 10 . -, Perfection. Medium-sized, soft salmon-pink flowers with blotches. Good grower and bloomer. 35 cts. each, $\$ 3$ for 10.

-, Prince of Orange. A true orange-colored Poppy Medium-sized flowers. Good, but not very strong grower. 35 cts. each, $\$ 3$ for 10.

-, Princess Ena. Salmon-pink, with orange blotches. Fine bloomer and good grower. 35c. ea., $\$ 3$ for 10.

-, Red Cap. Flowers of medium size, light scarlet. Low grower. 35 cts. each, $\$ 3$ for 10 .

-, Rembrandt. Large scarlet flowers with very prominent blotches. 35 cts. each, $\$ 3$ for 10 .

PENTSTEMON, Southgate Gem. New. One of the finest crimson-scarlet flowers. Fine for border and bedding and useful as a pot plant and in the bench. Blooms very freely the whole summer. Not quite hardy in the North but excellent in the southern states. Needs good protection. 35 cts. each, $\$ 3$ for 10 .

PETASITES japonica gigantea. Japanese Giant Butterbur. Very effective foliage plant for moist spots; leaves sometimes get as large as 2 to 3 feet in diameter. $3-4 \mathrm{ft}$. $\$ 1$ each, $\$ 9$ for 10 .

PHLOX decussata, Fraulein von Lassburg. A well known bright white variety. $25 \mathrm{cts}$. each, $\$ 2$ for 10 .

POTERIUM obtusum. The light pink flowers are borne on graceful stems and hang over the light green foliage like pink ears. Heavy bushes. 2 to $21 / 2 \mathrm{ft}$. June, July. 35 cts. each, $\$ 3$ for 10 .

PRIMULA auricula. A well-known and loved garden plant with fragrant flowers in various colors. 4 to 5 in. Early April and May. 50c. each, $\$ 4.50$ for 10 .

Denticulata cachemiriana. Stout, stiff stems, with round flower-heads of purple flowers. Very attractive. $10 \mathrm{in}$. to $1 \mathrm{ft}$. April, May. $50 \mathrm{cts}$. each, $\$ 4.50$ for 10.

PYRETHRUM, Rutherford. Double, dark wine-red blooms, with light pink center. Very fine. $1 \frac{1}{2}$ to $2 \mathrm{ft}$. June-summer. $\$ 1$ each, $\$ 9$ for 10.

Sylvia. Single, rose-pink flowers with light pink fringed edge and small yellow center. $1 \frac{1}{2}$ to 2 ft. June-summer. $\$ 1$ each, $\$ 9$ for 10 .

SALVIA farinacea. Long spikes of bright blue flowers. Not quite hardy. 2 to $3 \mathrm{ft}$. July, Aug. $25 \mathrm{cts}$. each, $\$ 2$ for 10 .

Nemorosa alba. An effective border plant like S. nemorosa, only with white flowers. $2 \mathrm{ft}$. May, June. 50 cts. each, $\$ 4.50$ for 10.

Sclarea. Blue and white flowers; large woolly foliage. 25 cts. each, $\$ 2$ for 10.

SENECIO clivorum, Othello. A fine variety of $S$. clivorum, with dark orange flowers. 3 to $4 \mathrm{ft}$. July, Aug. 50 cts. each, $\$ 4.50$ for 10 .

-, Orange Queen. Especially large, bright orangeyellow flowers. 4 to $5 \mathrm{ft}$. July, Aug. $50 \mathrm{cts}$. each, $\$ 4.50$ for 10 .

STOKESIA cyanea, Mixed. New colors. $2 \mathrm{ft}$. JulyOct. 25 cts. each, $\$ 2$ for 10.

TIARELLA purpurea major. Salmon Foam Flower. Strong grower. $11 / 2$ to $2 \mathrm{ft}$. June. $50 \mathrm{cts}$. each, $\$ 4.50$ for 10.

TRITOMA (Kniphofia) uvaria grandiflora. Orange yellow flowers. $3 \mathrm{ft}$. 25 cts. each, $\$ 2$ for 10 .

TROLLIUS Varieties. Globe Flower. For description see our Catalogue. 50 cts. each, $\$ 4.50$ for 10. 


\section{EVERGREENS, TREES, SHRUBS, VINES}

Our illustrated Evergreen Catalogue is replete with above products for every kind of planting. The following varieties of plants, however, have never been listed by us before, or have been omitted on account of scarcity. Other scarce varieties, such as Magnolias, Japanese Maples, Hybrid Rhododendrons, Ghent and Pontica Azaleas, and Blue Spruce of the real steel-blue color, we are now growing and can offer same in limited quantities, sizes and prices, upon request.

AZALEA longistylum. Allied to A. micranthum. Forms a beautiful shrub 6 feet high, with leaves from 1 to 2 inches long, pinkish flowers. 10 to 15 in., $\$ 2$ each; $11 / 2$ to $2 \mathrm{ft} ., \$ 3$ each.

CRATAGUS Arnoldiana. One of the most beautiful Hawthorns, with dark green foliage which turns to a beautiful scarlet in fall. Large white flowers in early spring and large, round, edible, scarlet fruit in August and September. A small-flowering tree suitable for group planting and near the seashore. 15 to $18 \mathrm{in.}, \$ 1$ each; $11 / 2$ to $2 \mathrm{ft}$., $\$ 1.50$ each; 2 to $21 / 2 \mathrm{ft}$., $\$ 2$ each; $21 / 2$ to $3 \mathrm{ft}$. $\$ 2.50$ each.

CYDONIA japonica, Pink. A pink form of the regular Japanese Quince. It is a very showy, popular shrub, bearing in early spring a profusion of beautiful pink flowers, shading to light salmon. 1 to $1 \frac{1}{2} \mathrm{ft}$., $\$ 1.50$ each; $11 / 2$ to $2 \mathrm{ft}$., $\$ 2$ each.

FORSYTHIA intermedia primulina. Upright shrub with spreading and arching branches. The yellow flowers are crowded at the bases of branches. 3 to $3 \frac{1}{2} \mathrm{ft}$., $\$ 1$ each; $3 \frac{1}{2}$ to $41 / 2 \mathrm{ft}$., $\$ 1.50$ each.

MALUS theifera (Pyrus theifera). One of the finest Malus varieties. Resembles a cherry tree, with stiff, spreading branches and beautiful white, fragrant flowers, both when in bloom in spring and in October with its light greenish yellow fruit with reddish cheek. Very rare. 4 to $5 \mathrm{ft}$., $\$ 5$ each; 5 to $6 \mathrm{ft}$., $\$ 6$ each; 6 to $7 \mathrm{ft}$., $\$ 7.50$ each.

PHILADELPHUS pubescens. This shrub reaches a height of 20 feet. The young branches are yellowish or greenish yellow, with large leaves. Its white flowers are borne in long leafy racemes of 5 to 10 , usually distant, and are slightly fragrant. 3 to $4 \mathrm{ft}$., $\$ 1$ each; 4 to $5 \mathrm{ft}$., $\$ 1.50$ each.

PHYSOCARPUS intermedius parvifolium. An ornamental shrub grown for its white flowers and bright green foliage. It reaches a height of 5 feet. 3 to $4 \mathrm{ft} ., \$ 1.50$ each.
PRUNUS mume. Japanese Apricot. A tree formed on the style of the common apricot, with foliage duller in color, small, narrow, ovate to nearly round, long pointed. The flowers, which appear in spring, are single, maroon-red followed by greenish yellow fruit in fall. 3 to $4 \mathrm{ft}$., $\$ 1.50$ each; 4 to $5 \mathrm{ft}$., $\$ 2$ each; 5 to $6 \mathrm{ft}$., $\$ 2.50$ each.

\section{EVERGREENS}

JUNIPERUS chinensis viridis. One of the finest Junipers of pyramidal form, with beautiful green foliage. 3 to $3 \frac{1}{2} \mathrm{ft}$., $\$ 7.50$ each; $31 / 2$ to $4 \mathrm{ft}$., $\$ 8.50$ each.

-Smithi. Scarce. This is the only Juniper which keeps a grass-green color during the winter. Branches are sparingly ramified and pendulous at tips; forms a broad, compact, pyramidal tree. 2 to $21 / 2 \mathrm{ft}$., $\$ 5$ each; $21 / 2$ to $3 \mathrm{ft}$., $\$ 6$ each.

PICEA canadensis Albertiana. Alberta Spruce. One of the most beautiful Evergreens. It is very symmetrical in form, dense, slow-growing with bluishgreen foliage. Very scarce. 12 to 15 in., $\$ 7$ each; 15 to 18 in., $\$ 8$ each; 18 to 24 in., $\$ 10$ each.

Pungens glauca Kosteri. The bluest of the Blue Spruces. This is the most remarkable and conspicuous of all the conifers for ornamental planting. Being symmetrical and shapely, its ideal purpose is as a specimen when, owing to its magnificent, vivid, bluish coloring, it constantly attracts the attention of all lovers of the beautiful. $2 \frac{1}{2}$ to $3 \mathrm{ft}$., $\$ 20$ each; 3 to $3 \frac{1}{2} \mathrm{ft}$., $\$ 25$ each; $3 \frac{1}{2}$ to $4 \mathrm{ft}$., $\$ 30$ each.

THU JA lutea, B. \& A. Showy bright yellowish green all through the winter, changing to golden yellow in spring. Forms a compact, broad pyramid, much superior to Lutea. 2 to $21 / 2 \mathrm{ft}$., $\$ 4$ each; $21 / 2$ to $3 \mathrm{ft}$., $\$ 5.50$ each; 3 to $3 \frac{1}{2} \mathrm{ft}$., $\$ 6.50$ each.




